\title{
Nasr Hamid Abu Zayd as a Modern Muslim Thinker
}

\author{
NUR ZAINATUL NADRA ZAINOL*, LATIFAH ABD MAJID \& \\ MUHD NAJIB ABDUL KADIR ${ }^{1}$
}

\begin{abstract}
Nasr Hamid Abu Zayd is a thinker who has produced works in the fields of theology, philosophy, law, politics and humanities. Abu Zayd's thought, partly on the Quran and its hermeneutics has stirred controversy in Egypt and the Muslim world. This research focuses on the controversy surrounding Nasr Hamid Abu Zayd which led to the declaration of his apostasy by the Supreme Court of Egypt in 1995, as well as his controversial thoughts on the Quran, its method of exegesis and certain fiqh (Islamic jurisprudence) issues such as the hijab (veil) and polygamy. This paper serves as a literature review which employs the content analysis as a methodology to elaborate on Abu Zayd's controversial thoughts based on his books, as well as through the views of Muslim and Western scholars on those thoughts.
\end{abstract}

Keywords: hermeneutics, modernism, Nasr Hamid Abu Zayd, Quranic exegesis

Nasr Hamid Abu Zayd (1943-2010) is an Egyptian Muslim intellectual whose expertise is in the field of Arabic language and Islamic Studies, namely in the hermeneutics research. Abu Zayd has served in the Department of Arabic Language, Faculty of Literature at Cairo University. His thought on the Quran has set off controversies, some of which are found in the books Mafhum al-Nass: Dirasah fi 'Ulum al-Qur'an and Naqd al-Khitab al-Dini. The controversy has forced Abu Zayd and his wife to migrate to the Netherlands. While in the Netherlands, he was appointed as a Professor of Arabic Language and Islamic Studies at Leiden University. Throughout his lifetime, he has authored books in Arabic and English. Those books have been translated into other languages, including Indonesian, Turkish, German and Italian. Besides that, Abu Zayd has penned many articles in both Arabic and English. His works have been translated into several languages such as German, French, Dutch and Indonesian. His works have prompted the rethinking of modern Islamic thought through critical discourses on the classical Islamic works (turath) in the field of theology, philosophy, law, politics and humanities.

The present paper is a qualitative, library research which involves literature reviews. The method employed is the content analysis of articles, books and discourses. Background information on the subject figure of this research has been obtained from the biography of Abu Zayd himself, Voice of an Exile: Reflections on Islam as well as other secondary sources which include previous research on Abu Zayd and his thought. On top of that, several academics have been interviewed by the author to gather their opinions on the Abu Zayd's thoughts.

\footnotetext{
${ }^{1}$ Nur Zainatul Nadra Zainol*(Corresponding author), Ph.D. Student at Dept. of al-Quran and al-Sunnah Studies, Faculty of Islamic Studies, Universiti Kebangsaan Malaysia, 43600 BANGI, Selangor, Malaysia, email: nadra@uthm.edu.my; Latifah Abd Majid, Ph.D., Assoc Prof. at Dept. of al-Quran and al-Sunnah, Faculty of Islamic Studies, Universiti Kebangsaan Malaysia, 43600 BANGI, Selangor, Malaysia, email: umilm@ukm.my; Muhd. Najib Abdul Kadir, Ph.D., Assoc. Prof. at Dept. of al-Quran and al-Sunnah, Faculty of Islamic Studies, Universiti Kebangsaan Malaysia, 43600 BANGI, Selangor, Malaysia, email: abunaseh@ukm.my.
} 


\section{Nasr Hamid Abu Zayd: A Biographic Sketch}

Abu Zayd was born on 10th June 1943 in a small village in Quhafa, near Tanta in Egypt. In the early childhood, he was exposed to the Quran when he was enrolled in the kuttab. The kuttab emphasized on the recitation and memorization of the Quran, as well as on academic matters such as reading, writing and arithmetic. According to Abu Zayd \& Esther (2004: 18) at eight years old, he has completed the memorizing of the Quran. During his adolescence age, he was mesmerized by the charisma and the struggle of Sayyid Qutb. According to Navid Kermani (1996: 170), Abu Zayd was involved in the al-Ikhwan al-Muslimin movement in Quhafa. In 1954 when he was eleven years old, Abu Zayd was imprisoned after allegedly charged with the involvement in the al-Ikhwan al-Muslimin movement. The ideology of al-Ikhwan al-Muslimin has made an impact on Abu Zayd during his youth, in terms of championing the social rights of the people and fighting against injustice.

On 1968, Abu Zayd (2004) furthered his degree studies in Cairo University and succeeded in attaining the Bachelor's Degree in Arabic Language and Literature in 1972. Following that, Abu Zayd pursued a master's degree in 1972-1977. Abu Zayd was granted a scholarship from the 'Ford Foundation Fellowship' to study at the Institute of Middle Eastern Studies at Pennsylvania University, Philadelphia, United States of America from 1978-1979. While in the US, he had an opportunity to do research on the philosophy of Western interpretation namely hermeneutics (Abu Zayd \& Esther 2004). According to Tamer (2011) Abu Zayd was able to immerse himself with various theories on modern interpretation and philosophical hermeneutic interpretation which was pioneered by Hans-Georg Gadamer. Studying the philosophy of Western interpretation in the US helped him acquired information to complete his Ph.D research (Abu Zayd \& Esther 2004). In 1981, Abu Zayd received the Doctor of Philosophy (Ph.D) from Cairo University through a dissertation entitled Falsafat al-Ta'wil: Dirasah fi Ta'wil al-Qur'an 'inda Muhyi al-Din ibn al- 'Arabi which was later published in 1983 (Navid Kermani 1996; Tamer 2011).

Based on the bibliographic author book entitle Voice of an Exile: Reflections on Islam, written by Abu Zayd \& Esther (2004) mentioned that Abu Zayd was a student of many eminent Muslims and Western figures, such as Hasan Hanafi, Abed al-Aziz al-Ahlawi who was the supervisor for his M.A and Ph.D, and Tom Neff who was the supervisor for his fellowship program in the United States. Besides that, he was impressed with outspokenness by Ali Abdul Raziq and has reviewed the case against him. In Islamic Studies, Abu Zayd admired Taha Husayn who questioned the authenticity of the poetry conceived in the pre-Islamic era, which roused controversy in Egypt and prompted the review of his work Fi al-Syi ri al-Jahili. Besides that, he also studied theory of literary critique on al-Quran by Amin al-Khulli and his student Muhammad Ahmed Khalafullah. Looking at the process of the advanced education received from those literary figures, it can be concluded that Abu Zayd had received education in Arabic language, Quranic Studies and philosophy from renowned figures in Egypt and the US to intensify the knowledge on the theory of Islam and Western interpretation. The knowledge gained by Abu Zayd was put into the development of Islamic thought and his career in the field of education and learning.

In the field of career, Abu Zayd began his academic career as an assistant lecturer at the Department of Arabic Language, Faculty of Literature in Cairo University in 1972. After receiving his M.A and Ph.D, Abu Zayd was appointed as Associate Professor in the Department of Arabic Language. According to Najjar (2000), Abu Zayd was a proficient lecturer, adored by his students and respected among his lecturer friends. In 1985-1989, he was a Visiting Professor at the School of Foreign Studies in Osaka University, teaching Arabic language, literature and Islamic thought, besides supervising master students. In Japan, Abu Zayd has had the chance to study on the theory of modern communication and analytical literature related to the semantics studies of the Quran by Toshihiku Isutzu (Tamer 2011). 
As a scholar, Abu Zayd's thoughts have been translated into writing form including research papers, articles, discourses and books. His writing encompasses the fields of theology, philosophy, law, politics and humanities. Among the works of Abu Zayd are: Al-Ittijāh al-'Aqli fi al-Tafsir: Dirasah fi Qadiyat al-Majaz fi al-Qur'an 'inda al-Mu'tazilah, Falsafat al-Ta'wil: Dirasah fi Ta'wil al-Qur'an 'inda Muhyi al-Din ibn al-'Arabi, Mafhum al-Nass: Dirasah fi 'Ulum al-Qur'an, Ishkaliyat al-Qira'ah wa-Aliyat al-Ta'wil, Al-Imam al-Shafi i wa Ta'sis al-Idiyulujiyah alWasatiyah, Naqd al-Khitab al-Dini, al-Mar'ah fi Khitab al-Azmah, Al-Tafkir fi Zaman al-Takfir, The Quran: God and Man in Communication, Rethinking the Quran: Towards a Humanistic Hermeneutics, and Voice of an Exile: Reflections on Islam.

\section{Abu Zayd and His Controversial Views}

Abu Zayd's thoughts on theology, specifically on the Quran have been cited in his works in both Arabic and English. The articles serve to address several thoughts of Abu Zayd which have caused controversy in the Muslim world and led to the verdict of his apostasy. Among Abu Zayd's thoughts which have stirred controversy were on the Quran, the theory of Quranic exegesis, and several fiqh (Islamic jurisprudence) issues such as polygamy and the hijab (veil).

\section{The Quran is a Text}

The Quran is not defined as the Word of God (Kalam Allah) that is preserved in the Luh alMahfuz (fi al-lawh al-mahfuz) in Arabic alphabets. In his book Mafhum al-Nass, Abu Zayd (1998) is of the view that the Quran is a nasslughawi (literary text) that is closely related to a particular culture or racial context, which is the Arabian society. Muslims' over-emphasis on the divine dimension according to him is one of the contributing factors to the stagnancy and rigidity of Islamic thought. He added that the Quran is in fact 'the words of Muhammad reporting what he asserts is the Word of God'. Abu Zayd argued that the Quran possesses human characteristics, since Allah the Almighty wishes to convey His guidance to humanity. If Allah were to communicate in a divine language, humanity would have not been able to comprehend the guidance. As a result, in Abu Zayd's opinion, the Quran is human language; the change from divine text into human text has taken place since the first revelation to Prophet Muhammad. Abu Zayd maintains that:

\footnotetext{
The text, since it was first sent down -when it was revealed and read by the Prophet- has gone through a change from divine text to human text, for it has changed from being a tanzil (sent-down message) to takwil (an interpretation of the message). Muhammad's comprehension of the text demonstrated the earliest stage of interaction between the text and a human mind (Abu Zayd 1998).
}

Abu Zayd's thought on the Quran as a human text has set off a polemic in the Muslim world. The statement has undermined the elevated status of the Quran as a book of miracles to the Messenger of Allah (peace be upon him). Muslims believe that the Messenger is not an author; he was the informer of Allah's revelation, as mentioned in the verse (al-Quran 5:15).

O People of the Scripture, there has come to you Our Messenger making clear to you much of what you used to conceal of the Scripture and overlooking much. There has come to you from Allah a light and a clear Book.

Hermeneutics as an Approach to Interpreting the Quran

According to M. Nur Kholis Setiawan (2005) in the book Al-Quran Kitab Sastra Terbesar, Abu Zayd was of the same generation as Amin al-Khulli, who was a propagator of the adabi (literary) 
method in Quranic research. According to Mazlan et al. (2010), Abu Zayd was also said to be one of the modern Muslim figures who regarded hermeneutics as part of the Islamic scholarly. It was also claimed that utilizing the hermeneutics concept in the interpretation of the Quran is an imitation of the Muktazilite concept. Abu Zayd's involvement in hermeneutics began when he regarded the Quran as a textual entity that embodied the characteristics of Arabian culture and that it has to be interpreted based on the realities of culture and society (Abu Zayd 1998). According to Navid Kermani (1996) in the article, From Revelation to Interpretation: Nasr Hamid Abu Zayd and the Literary Study of the Quran, Abu Zayd employed the hermeneutic methodology by justifying that the Quran needs to be interpreted through the present historical and cultural contexts. Abu Zayd claimed that Muslim scholars are erroneous when they perceive the Quran as merely a body of texts. Thus, Abu Zayd proposed a new concept of interpretation of the Quran through the theory of hermeneutics. This theory has caused grave controversy which led to the clash between conservative and liberal thoughts. The clash between conservatives and liberals, according to Abu Zayd, has resulted in the competence of hermeneutics.

Charles Hirschkind (1995: 468) mentioned that Abu Zayd was one of the modern Muslim scholars who explored semantic analysis, which came with the theory of dalälah and maghza $\bar{a}$ to the Quranic text. While interpreting verses of the Quran, Abu Zayd employed the theory of dalälah and maghzā in order to acquire the dalālah asliyyah (Hirschkind 1995; Najjar 2000). The theory was conceived from an American linguist Eric D. Hirsch Jr. (1978: 8) through his work entitled Validity in Interpretation. Abu Zayd then proposed the theory of interpretation based on the interaction between a text and its cultural system. He distinguished between the meaning (dalalah) and the significance (maghza) (Poggemiller 1995). Thus, Abu Zayd was regarded as one of the modern Muslim thinkers who rejected the method of interpretation that was agreed upon by the scholars of exegesis (mufassir) by applying hermeneutics in the interpretation of the Quran (Nur 2012). As a result, the method of interpretation introduced by Abu Zayd has caused the syariah (Islamic laws) to be relative and variable (Adian Husaini \& alBaghdadi 2007). The Abu Zayd's interpretation method has instigated controversial fiqh issues, such as the legitimacy of polygamy and the hijab in the Muslim community.

\section{Polygamy is a Forbidden Practice}

The legislation of polygamy in Islam is established based on the Quranic verse (al-Quran 4:3):

And if you fear that you shall not be able to deal justly with the orphan-girls, then marry (other) women of your choice, two or three, or four, but if you fear that you shall not be able to deal justly (with them), then only one or (the captives and the slaves) that your right hands possess. That is nearer to prevent you from doing injustice.

The book Voice of an Exile: Reflections on Islam (Abu Zayd \& Esther 2004: 172) stated on his on polygamy. He viewed it was erroneous to consider polygamy as part of the revelation from Allah. He clarified that according to the historical context, the verse (al-Quran 4:3) only deliberated on the issue of the orphans who needed care and protection after losing their parents in the battle of Uhud. Furthermore, looking at the textual analysis of the verse (alQuran 4:3), the permission to wed a widow or an orphan girl is just so they may be protected and cared for accordingly, as the norm of the society of that era would suppress the widows and orphans by misusing their inheritance (Abu Zayd \& Esther 2004). As for Abu Zayd's interpretation of verse $(4: 129)$ of al-Nisa, he pointed out to the verse that justice which is an obligation in polygamy is highly unachievable, thus rendering polygamy as forbidden to be practiced in terms of the present context. Abu Zayd stressed that polygamy is not a law, but rather it serves as a practical solution to the problem of orphans. If the Arab society chooses to wed the orphans, the injustice dilemma would not be realized (Abu Zayd \& Esther 2004). In today's social context, Abu Zayd is of the opinion that polygamy is undermining women and 
children. He believes fairness is the most significant issue to be accentuated in a community based on the verse of al-Nisa' (4:129). He concluded that the Quran rejects polygamy practices as it was a solution to the social problem that occurred during that period after the battle of Uhud, which saw the martyrdom of many Muslims; resulting in a many uncared for orphans, at which point the Quran permits Muslims of the time to practice polygamy (Abu Zayd 1994).

In interpreting al-Nisa' verses 3 and 129, Abu Zayd employed the contextual interpretation (Adnin Armas 2005; Nur 2012). Abu Zayd applied the hermeneutics methodology which subscribes to the theory of meaning (dalālah) and significance (maghzā) (Abu Zayd 1994). Polygamy in the Quranic discourse portrays a third-level meaning; the meaning could be expanded based on the significance established in the social-cultural context, whereby the text is applied (Abu Zayd 1994). Abu Zayd's opinion on polygamy is contrary to the opinion of the majority scholars (jumhur) and the predecessor interpreters of the Quran (mufassir salafi) namely the likes of al-Tabari and Ibn Kathir. With regards to polygamy, al-Tabari (2005) in his exegesis stressed on the justice aspect of a marriage institution, whether it involves the case of marrying orphans, or free women, or the practice of polygamy itself. His opinion is evident in his commentary on surah al-Nisa'verse 3:

If you fear the possibility of being unjust, while married to orphans, wed, then the righteous ladies who have been permitted for you up to a maximum of four wives. However, if you fear of being unjust to all your wives, wed then only one. And if you still fear of being unjust, wed, then one from amongst the women slaves, for that is safer than for you to be unjust and ill-treat them.

Meanwhile, Ibn Kathir (2000) is of a similar opinion with al-Tabari with regards to polygamy: justice or fairness should be the backbone of polygamy. However, if there is no justice in terms of the husband's treatment, sharing of dressing, house, night stay schedule among other things, a person will have to choose to practice monogamy. With respect to the number of wives that is permitted in marriage, according to Imam Syafie, based upon the tradition of the Messenger (peace be upon him), the number is four. This opinion became agreed upon among all the scholars, except for the Shi'ites.

\section{The Hijab is an Arabian Culture}

In Islam, covering the 'awrah (intimate parts of the body) is part of the Shariah that is commanded to all Muslims. Muslim women are obliged to put on the hijab to preserve their 'awrah from being exposed. This command is based on the verse in al-Nur (al-Quran 24:30-31):

Tell the believing men to lower their gaze (from looking at forbidden things), and protect their private parts (from illegal sexual acts, etc.). That is purer for them. Verily, Allah is All-Aware of what they do. And tell the believing women to lower their gaze (from looking at forbidden things), and protect their private parts (from illegal sexual acts, etc.) and not to show off their adornment except only that which is apparent (like palms of hands or one eye or both eyes for necessity to see the way, or outer dress like veil, gloves, head-cover, apron, etc.), and to draw their veils all over their chests (i.e. their bodies, necks and bosoms, etc.) and not to reveal their adornment except to their husbands, their fathers, their husband's fathers, their sons, their husband's sons, their brothers or their brother's sons, or their sister's sons, or their (Muslim) women (i.e. their sisters in Islam), or the (female) slaves whom their right hands possess, or old male servants who lack vigour, or small children who have no sense of the shame of sex. And let them not stamp their feet so as to reveal what they hide of their adornment. And all of you beg Allah to forgive you all, 0 believers, that you may be successful. 
Abu Zayd in his book Dawa'ir al-Khawf (1999) mentioned that the 'awrah is something which is changeable and not fixed. The concept of 'awrah is closely related to the social-cultural situation of a particular society, whereas the issue of hijab is also associated with social customs. Abu Zayd interpreted the verses (al-Quran 24:30-31) on covering the 'awrah and putting on the hijab as subjected to the social-cultural norms. The culture of hijab varies from one community to another. Thus, Abu Zayd's view on the hijab and the 'awrah are not legislated in Islam as they are part of the culture of the Arabs. This opinion opposes the opinion of the majority of the scholars on the 'awrah and hijab; the verse (al-Quran 24:30-31) is universal in its nature, which renders the covering of the 'awrah and donning the hijab for all Muslim women a religious obligation throughout the ages, and not reserved only for Arab ladies (Adian Husaini \& al-Baghdadi 2007: 24).

\section{The Case of Abu Zayd}

Abu Zayd's thought has sparked off a phenomenon in Egypt and the Arab world due to his opposing thoughts against the opinions of the majority scholars, especially on the Quran and his criticism of the predecessor (salafi) scholars. The following is the chronology of controversies involving Abu Zayd:

\section{The Controversy over Abu Zayd's Promotion to 'Professorship'}

In his career, Abu Zayd did not escape from trials and tribulations. The ordeal began as a result of his promotion on 9 May 1992, when he applied for a promotion to a professorship in the Department of Arabic Language. He had submitted his application together with eleven research papers and two of his own books to the university's Committee for Appointment and Promotion. The committee then handed over the materials to be vetted by a small committee of three Professors; `Abd al-Sabur Shahin, Mahmud `Ali Makki and `Awni `Abd al-Ra'uf. The task of the Appointment Committee is to write a report based on the assessment made by the small committee, before submitting it to the Dean of Faculty. The result released by the committee is 2-1; Shahin did not support the application.

'Abd al-Sabur Shahin (1995) maintained that Abu Zayd's works could not be regarded as an academic research since those works are in-line with a group of writers who believe in intellectual terrorism. Besides that, the report given by Shahin (1995), he rejected the Abu Zayd's research because of the multiple copies of the mushaf (a book compilation of chapters and verses of the Quran), the argument on the human dimension of the Quran and the application of reason in interpreting the Quran. On top of the assessment on the research quality of Abu Zayd's works, Shahin also claimed that Abu Zayd's works are trivial and do not reflect his status as an academic scholar. Thus, Shahin asserted that Abu Zayd's articles are featured in limited edition journals; his book on al-Imam al-Shafi'i contained a mere 110 pages, which, according to Shahin do not resemble his scholarly status.

\section{The Controversial Case of Abu Zayd's Apostasy and the Annulment of Marriage}

On 2 April 1993, Shahin (1995) publicly declared Abu Zayd as an apostate during a Friday sermon delivered in Masjid Amr ibn al-'As as his works have been regarded as 'AIDS culture' and 'an attempt of the Secular-Marxist to disrupt the Egyptian Muslim community'. Afterwards, preachers in mosques all over Egypt followed the footsteps of Shahin by reiterating the same words (Najjar 2000). The case of Abu Zayd stretched until the process of the annulment of his marriage. Once he was declared an apostate on 10 June 1993, Muhammad Samida Abd alSamad, a Muslim lawyer, together with his six associates presented the case of Abu Zayd to the Department of Public Affairs at the Giza Subordinate Court. Because of Giza Subordinate Court 
did not practice the shariah laws on apostasy, thus Abd al-Samad and his associates used to hisba laws for the case of Abu Zayd. They declared to separate the marriage between Abu Zayd from his spouse on the basis of his apostasy and that it is not permissible for a Muslim woman to wed a non-Muslim man. The case of Abu Zayd involved the principle of hisbah. Abd al-Samad and his associates accused Abu Zayd of publishing works which mounted to the declaration of his apostasy by the Islamic scholars. The newspaper Liwa' al-Islami on 15 April 1993 published a column entitled: "Abu Zayd the Deviated" which revealed Abu Zayd as a treacherous man who puts his students at risk, and thus urged the rector of Cairo University to dismiss him from his post. Albeit all the controversies surrounding Abu Zayd's research, ultimately he was still conferred the professorship by Cairo University (Abu Zayd \& Esther 2004). On 14 June 1995, the Egypt Appeal Court declared Abu Zayd an apostate based on his works (Weaver 1998). The court's conclusion on Abu Zayd (1998: 52) is as follows: (a) Rejection of the existence of elements of ghaibiyyat (metaphysics) such as angels and demons as stated in the Quran; (b) A presumption that the description of paradise and hell-fire is fictitious; (c) Believing that the Quran is a human (not divine) text, and (d) The promotion of exercising reason to substitute the concepts deduced from the harfiyyah (word for word) understanding of the Quran with modern, humanistic and progressive concepts of understanding the Quran, especially on verses concerning inheritance, women, ahl al-Zimmah (Jews and Christians) and women slaves.

After the Court's verdict on Abu Zayd's apostasy, several issues arise, including the request for the annulment of his marriage. Since the law denies the marriage of a non-Muslim to a Muslim, the court pronounced the marriage of Abu Zayd to Ebtehal as void legally, and thus dissolved. A fatwa was issued by Ayman al-Zawahiri, who proclaimed the obligation of Muslims to kill Abu Zayd. On top of that, al-Azhar scholars have called the government to exercise the penalty for apostasy, which is death. Shahin remarked on the decision of the Appeal Court, saying: "The Court has made the decision after reviewing the case for more than two years, and it is certain that Abu Zayd is an apostate who has to be separated from his spouse" (Najjar 2000).

Following the incident, the case of Abu Zayd received an extensive coverage from all sides, including local and global communities, besides receiving death threats from militants who were dissatisfied with him (Sfeir 1998). The situation prompted the authorities to secure the safety of Abu Zayd and his wife. Abu Zayd (2004) described the moment as like being in a prison. On 5 August 1996, the Egypt Supreme Court approved the verdict of the Appeal Court that was declared on 14 June 1995 on the issue of Abu Zayd's apostasy, and confirmed the reasons which led to the verdict are as follows: (a) Describing elements such as the Throne ('arash), God, angels, devils, demons, paradise and hell-fire as ancient tales, (b) Proclaiming the Quran as a cultural product, thus denying the existence of its eternal existence in Luh Mahfuz, (c) The Quran is a linguistic text, which in turn claims that the Messenger lied about receiving revelation from Allah, (d) Proclaiming the knowledge from the Quran as a 'cultural inheritance' as well as proclaiming the Shariah is the factor of backwardness and the decline of Muslims, (e) Proclaiming the belief in the qada' and qadar (Allah's will) reflects a mind drowned in tales, (f) Proclaiming Islam as a religion of the Arabs, thus rejecting Islam's universality, (g) Reiterated that the final version of the Quran was produced in accordance with the language of the Quraish to prove its superiority, (h) Denying the authenticity of the tradition (sunnah) of the Messenger, (i) Calling towards the freedom from religious text dominance, and (j) Considered the submission to religious text as a form of slavery ( Najjar 2000: 194-195; Abu Zayd 1998).

The case of Abu Zayd has been discussed and highlighted by Western scholars. They discussed it in different scopes and areas in term of apostasy in Shari'ah laws, human rights and right to express of the view and idea. Among of the scholars are the work of Charles Hirschkind in the article entitled Heresy or Hermeneutics: The Case of Nasr Hamid Abu Zayd (1995), Kilian Balz (1997) Submitting Faith to Judicial Scrutiny through the Family Trial: The Abu Zayd Case, George N. Sfeir in the article Basic Freedom in a Fractured Legal Culture: Egypt and the Case of Nasr Hamid Abu Zayd (1998: 402-14), Najjar in the article entitled Islamic Fundamentalism and 
the Intellectuals: The Case of Nasr Hamid Abu Zayd (2000: 177-200), Augustus Richard Norton (2001: 380) Activism and Reform in Islam, Jorn Thielmann (2003) Nasr Hamid Abu Zayd und die Wiedererfunene Hisba: Sari'a und Qanun im Heutigen Agypten, and Maurits S. Berger (2003) in the article Apostasy and Public Policy in Contemporary Egypt: An Evaluation of Recent Cases from Egypt Highest Courts.

\section{Living in Exile}

As a result of apostasy incident, he has received death threats from the Egyptian extremist group. Consequently, he and Ebtehal decided to leave Egypt. Earlier, Ebtehal was planning to leave for Madrid by herself in September since she was granted a fellowship award. However, due to the incident that happened to her husband, they decided to leave for Spain before moving on to live in the Netherlands. On the night of 23 July 1995, Abu Zayd and his wife left Egypt and were determined not to return to Egypt, so as not to live in a prison following the pressure and threats they received. On 25 October 1995, Abu Zayd arrived in Leiden, the Netherlands. Throughout his life in exile, he has been active in education and writing. Abu Zayd was appointed Professor of Arabic Language and Islamic Studies at Leiden University as well as the supervisor for M.A and Ph.D students there. Besides that, he was also the holder of the 'Cleveringa Chair' at Leiden University (Abu Zayd \& Esther 2004). He also held the 'Ibn Rushd Chair of Humanism and Islam' at the University for Humanistics, Utretch, the Netherlands. He constantly took part in research projects at Jewish and Islamic hermeneutics as a critic on Islamic culture and modernization at the Berlin Institute for Advanced Studies (Wissenschaftskolleg zu Berlin) in Germany (Kersten 2010). Abu Zayd's thought was wellreceived by the Western community. His ideology of struggling for the freedom of expression in Islamic discourses was recognized by the West. In 2005, Abu Zayd received the Ibn Rushd Fund for the Freedom of Thought award (Abu Zayd \& Esther 2004) for his contributions in the struggle for freedom of expression. According to George Tamer (2011) Abu Zayd passed away on 5 July 2010 in Cairo Hospital after he was infected with an unidentified virus in Indonesia. His passing was mourned by his friends who admire his passion in Islamic and Quranic discourses.

As a conclusion, his learning stint in the United States had exposed him to the theory of Western interpretation, while his study in Egypt expanded his research on the Islamic theory of interpretation such as the Muktazilite and the interpretative theory of Ibn Arabi. Critical interpretative literary theories and semiotics from the hermeneutics method have been applied for interpretation of the Quran. Abu Zayd has undermined the status of the Quran by equating it to other works of literature. Re-interpretation of the Quran based on the present context has turned fiqh issues such as polygamy and the hijab into a controversy which opposes the majority of the scholars. According to al-Khalidi, the book Mafhum al-Nass can be regarded as tafsir bi al-ra'y that is rejected (mazmum) as the interpretation is made based on desires without any evidence, and thus it is considered as deviated from the true meanings (al-Khalidi 2010; Nur 2012). Moreover, the method of interpretation introduced by Abu Zayd is under the category of deviating Quranic exegesis (al-Khalidi 2010; Mazlan Ibrahim \& Achmad Yaman 2010). Although Muslim scholar such al-Khalidi rejected method of interpretation by Abu Zayd, however Abu Zayd's thought was honored by Western Scholar and it was well-received by them.

\section{References}

Abu Zayd, Nasr Hamid. 1991. Mafhum al-nass: Dirasah fi 'Ulum al-Qur'an, Cairo: al-Markaz alSaqafi al-'Arabi.

Abu Zayd, Nasr Hamid. 1995. Al-mar'ah fi khitab al-azmah. Cairo: al-Markaz al-Saqafi al-`Arabi. Abu Zayd, Nasr Hamid. 1998. Al-tafkir fi zaman al-takfir. Cairo: al-Markaz al-Saqafi al-`Arabi. 
Abu Zayd, Nasr Hamid. 1998. Falsafat al-ta'wil: Dirasah fi ta'wil al-Qur'an 'inda Muhyi al-Din ibn al-'Arabi. Cairo: al-Markaz al-Saqafi al-'Arabi.

Abu Zayd, Nasr Hamid. 1998. Inquisition trial in Egypt. Recht van de Islam 15.

Abu Zayd, Nasr Hamid. 1998. Naqd al-khitab al-dini. Cairo: al-Markaz al-Saqafi al-`Arabi.

Abu Zayd, Nasr Hamid. 1999. Dawair al-khawf: Dirasah fi khitab al-mar'ah. Cairo: al-Markaz alSaqafi al-`Arabi.

Abu Zayd, Nasr Hamid. 2000. Al-khitab wa al-ta'wil. Lubnan: al-Markaz al-Saqafi al-`Arabi.

Abu Zayd, Nasr Hamid. 2000. The Quran: God and man in communication. Leiden: Inaugural Lecture.

Abu Zayd, Nasr Hamid \& Esther, R. Nelson. 2004. Voice of an wxile: Reflections on Islam. New York: Praeger Publishers.

Adian Husaini \& Abd al-Rahman al-Baghdadi. 2007. Hermeneutika \& Tafsir al-Quran. Jakarta: Gema Insani.

Adnin Armas. 2005. Metodologi Bibel dalam al-Quran. Jakarta: Gema Insani.

Balz, Killian. 1997. Submitting faith to judicial scrutiny through the family trial: The Abu Zayd Case. Die Welt des Islams. 37(2): 135-155.

Berger, Maurits S. 2003. Apostasy and public policy in contemporary Egypt: An evaluation of recent cases from Egypt Highest Courts. Human Rights Quarterly. 25: 720-740.

Hirsch, Jr. Erich. D. 1978. Validity in interpretation. New Haven and London: Yale University Press.

Hirschkind, Charles. 1998. Heresy or hermeneutics: The case of Nasr Hamid Abu Zayd. The American Journal of Islamic Social Sciences 12(4).

http://caroolkersten.blogspot.com/2010/07/nasr-hamid-abu-zayd-1943-2010.html [12/11/2012].

http://ibn-rushd.org/pages/int/Awards/2005/documents/cv-en.html [10/11/2012].

http://www.deenresearchcenter.com/DRC/NasrAbuZaydslegacy/tabid/108/Default.aspx [10/11/2012].

Ibn Kathir, Ismail ibn 'Umar. 2000. Tafsir al-Quran al-'Azim. Cairo: al-Faroq al-Hadisah li alTibaah wa al-Nash.

Imara, Muhamamad. 1996. Al-Tafsir al-Marxi li al-Islam. Cairo: Dar al-Shuruq.

Kermani, Navid. 1996. From revelation to interpretation: Nasr Hamid Abu Zayd and the literary study of the Quran. Trans. Frankfurt, pp. 169-192.

Kersten, Carool. 2010. Islam, Cultural hybridity and cosmopolitanism: New Muslim intellectuals on globalization. Journal of International and Global Studies, pp. 89-113.

al-Khalidi, Sallah Abd al-Fattah. 2010. Takrif al-darisin bi manahij al-mufassirin. Damascus: Dar al-Qalam.

Mazlan Ibrahim \& Achmad Yaman. 2010. Penyelewengan tafsir al-Quran: Kritikan terhadap buku 'Fiqih lintasan agama'. Bangi: Penerbit Universiti Kebangsaan Malaysia.

Muhammad Nur Kholis Setiawan. 2005. Al-Quran kitab sastra terbesar. Yogyakarta: eLSAQ Press.

Najjar, Fauzi M. 2000. Islamic fundamentalism and the intellectuals: The Case of Nasr Hāmid Abu Zayd. British Journal of Middle Eastern Studies 27(2): 177-200.

Norton, Augustus Richard. 2002. Activism and reform in Islam. Current History A Journal of Contemporary World 101(658): 377.

Nur Zainatul Nadra, Zainol. 2012. Poligami menurut pandangan Nasr Hamid Abu Zayd. Paper presented at the World Conference on Islamic Thought 2012. Kolej Universiti Islam Sultan Azlan Shah, Perak.

Poggemiller, Dwight. 1995. Hermeneutics and epistemology: Hirsch's author centered meaning, Radical Historicism and Gadamer's Truth and Method. Premise Journal 2(8).

Sfeir, George N. 1998. Basic freedom in a fractured legal culture: Egypt and the case of Nasr Hamid Abu Zayd. Middle East Journal 52: 402-14.

Shahin, 'Abd al-Sabur (ed.). 1995. Qissat Abi Zayd wa inhisar al-'almaniyya. Cairo: Dar al-Ictisam. 
al-Tabari, Abu Ja`afar Muhammad ibn Jarir (d.310H). 2005. Jami' al-bayan fi ta'wil ayat alQur'an. Beirut: Dar al-Salam.

Tamer, Georges. 2011. Obituary Nasr Hamid Abu Zayd. International Journal of Middle East Studies, pp. 193-195.

Thielmann, J. 2003. Nasr Hamid Abu Zayd und die Wiedererfunene Hisba: Sari'a und Qanun im Heutigen Agypten. Germany: Ergon.

Weaver, Mary Anne. 1998. Revolution by stealth. The New Yorker. June, 8. 